\title{
The significance of milk ring test for identifying brucella antibodies in cows and buffaloes' raw milk at Erbil governorate, Kurdistan region, Iraq
}

\author{
D.A. Al-Mmashhadany \\ Department of Pathological Analysis, College of Science, Knowledge University, Erbil, Iraq
}

(Received November 12, 2018; Accepted December 21, 2018)

\begin{abstract}
This study was undertaken to monitor Brucella antibodies in the milk of cows and buffaloes in Erbil Governorate, Kurdistan Region, Iraq, using mik ring test (MRT) assay. A total of 210 samples of milk (130 from cows and 80 from buffaloes) were randomly collected from lactating females. The overall prevalence of Brucella antibodies in all the milk samples was $8.6 \%$ (18/210). The highest rate was $9.2 \%$ found in the cow milk (12/130), while the lowest rate was $7.5 \%$ of the buffalo's milk (6/80). Out of 210 milk samples, only 15 (7.1\%) were culture-positive for Brucella; about $\vee .7 \%(10 / 130)$ and $6.3 \%(5 / 80)$ from cows and buffaloes respectively. In terms of comparison between MRT and standard milk culture method, MRT was found more sensitive (83\%), specific (98\%), with the accuracy of $97 \%$ in comparison to the employed culture approach to detect Brucellosis agents in milk. The results also revealed that $70 \%$ and $60 \%$ of isolates were Brucella abortus, while $30 \%$ and $40 \%$ were Brucella melitensis from the milk of cow and buffaloes respectively. The highest rate of frequency for Brucella antibodies according to MRT was found in February (12.1\%), while the lowest rate was found in June (5.7\%). This study emphasizes that Brucellosis is still a significant public health hazard in the Kurdistan region. The study recommends MRT adoption in routine monitoring of brucellosis in milk collection centre, dairy factories, and farm. Consumers are also recommended to sufficiently heat the milk to destroy this foodborne pathogen before consumption or industrial processing.
\end{abstract}

Keywords: Brucella antibodies, Milk, MRT sensitivity, Brucella abortus, Brucella melitensis Available online at http://www.vetmedmosul.com

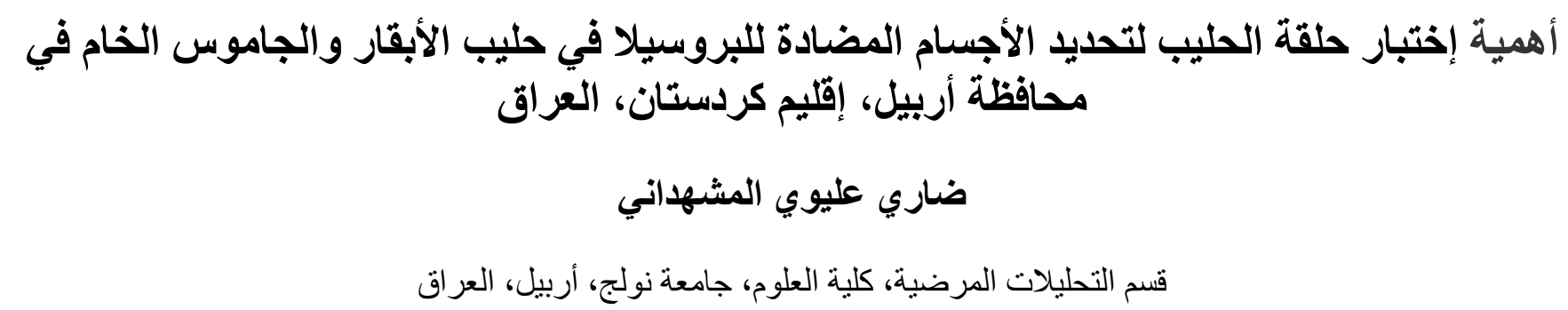

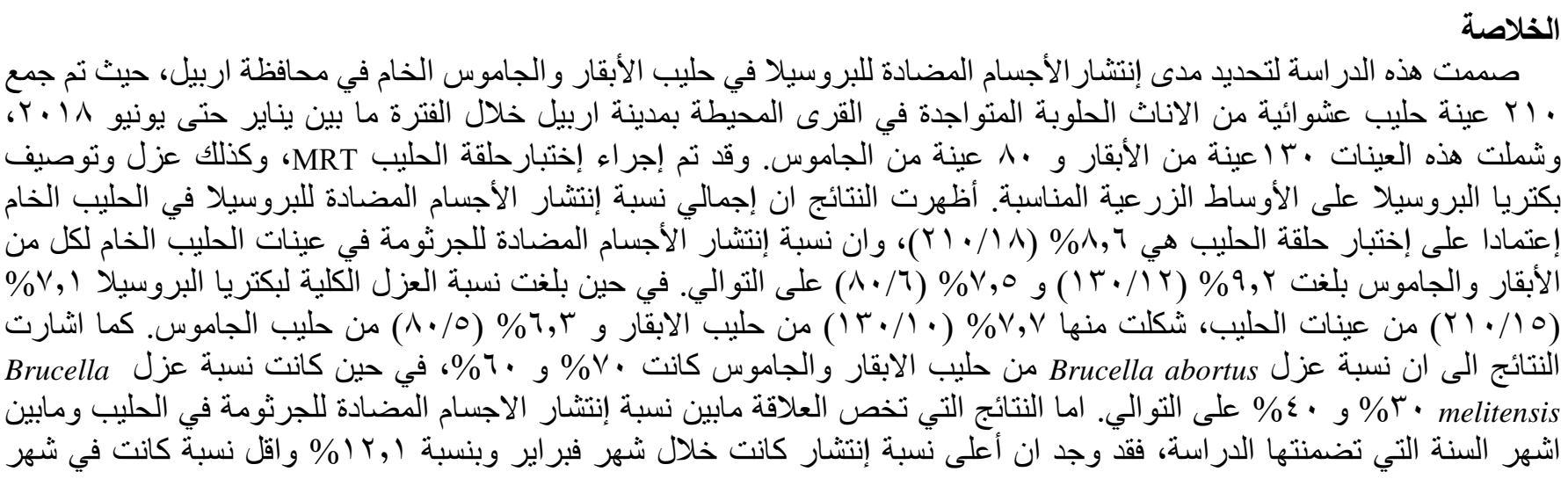




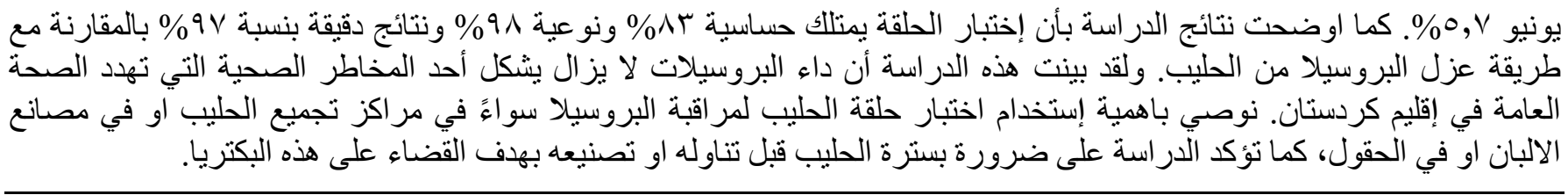

\section{Introduction}

Brucellosis is a cosmopolitan bacterial zoonotic disease (caused by Brucella spp.) that affects humans and various species of the wild and domestic animals, particularly foodproducing animals, including large and small ruminants such as cattle, buffaloes, camels, sheep, goats, pigs, and reindeer. Through the previous two decades, the infection has also been recognized in marine mammals, including beaked whales, dolphins, cetaceans, porpoises, and seals, which may present an emerging risk to individuals professionally exposed to contaminated tissues from such animals. This disease is highly infectious with a contagious dose of 10-100 cells are adequate to cause systemic infection $(1,2)$.

Brucellosis is a foodborne and professional zoonotic disease, caused by the bacterial genus Brucella. This infection has an extremely emerging and significant reemerging potentials in numerous countries. In addition, it is the major cause of direct financial losses due to the major hindrance for international trade of milk, meat, and their products $(3,4)$. The transmission occurs through ingestion of contaminated milk or meat and from mothers to breastfed babies. The transmission of Brucella also occurs through mucous membranes or skin wounds, following direct contact with urine, vaginal discharges, blood, tissues, placenta, aborted fetuses, and through inhalation of airborne agents in an atmosphere $(5,6)$. Human brucellosis is a severely debilitating and disabling life-threatening disease. It is recognized by the clinical problems such as, the contribution of the interior organs, peripheral arthritis, bronchopneumonia, epididymitis, orchitis, hepatic abscesses, sacroiliitis, osteomyelitis, spondylitis, meningitis, encephalitis, cardiovascular complications, and prostatitis $(7,8)$.

Brucellosis is found worldwide, but predominates in the countries of the Middle East, Mediterranean countries, Africa, Asia, Central and South Americas, however, some developed countries are essentially free of brucellosis $(9,10)$. The international map of human brucellosis has considerably changed over the last decade as a consequence of complex factors (11). According to statistics of the World Health Organization (WHO), more than 500,000 new cases of brucellosis are registered worldwide annually. Nonetheless, several researchers estimate that the number of human brucellosis cases may be up to 26 times higher than the figure stated above (12).
Microbiologically, Brucella spp. are intracellular, nonmotile non-sporing gram-negative short rods. They are aerobic, but some strains require $5-10 \% \mathrm{CO}_{2}$ for primary isolation. Growth in vitro is slow and primary isolation may require up to 4 weeks of incubation at $37^{\circ} \mathrm{C}$. The colonies appear shiny surface on transparent media usually after 4-5 days of incubation. Brucella colonies are smooth, transparent, raised, convex with an entire edge, punctuate, and non-hemolytic. Biochemically, carbohydrates are not fermented and aerobic oxidation is the sole energyproducing process $(13,14)$. To date, twelve Brucella species have been reported each species may infect a different host group, but species have a preference to certain host category $(15,16)$.

Recently, Jaff reported that the occurrence of human brucellosis in Kurdistan region, Iraq is still higher than recorded from bordering countries. Brucella infections have been reported from all three Iraqi Kurdistan governorates (17). The same study had also pointed out that the frequency proportion of brucellosis among cattle in 2012 was $10.7 \%$ in Erbil city, 6.36\% in Dohuk in 2011, and 976 cases among Sulaimani governorate in 2013. In Kurdistan region, people consume milk of the various animals including; cows, buffaloes, ewes, nanny goats, and camels which had been reported as a source of infection.

Milk Ring Test (MRT) was first qualified in Germany by Fleischhauerat 1937, it is the first-line routine checking test for individual dairy female and potentially infected flocks for brucellosis. MRT is an easy, simple, satisfactory, inexpensive, time-saving, and effective method to monitor brucellosis in milk-producing herds. It primarily detects IgA and IgM antibodies against Brucella spp. in raw milk. The sensitivity and specificity of MRT have reported to be $85 \%$ and $95 \%$, respectively $(18,19)$.

The study aimed to monitor the sero-prevalence of brucellosis among cattle and buffalo population in Erbil city and to calculate the sensitivity and specificity of MRT in comparison to traditional bacterial culture approach. The correlation between months of the study and frequency of Brucella antibodies in milk was also investigated.

\section{Materials and methods}

\section{Samples Collection and Transport}

A total number of raw milk samples was 210 (130 from cows and 80 from buffaloes) that were collected from lactating females from villages around Erbil city, during the 
period from January to June 2018. The milk samples (100 $\mathrm{ml}$ for each) were collected into sterile plastic containers with screw lids under sterile hygienic conditions (20). All the samples were transported on ice to the Laboratory of Microbiology at Pathological Analysis Department, College of Science, Knowledge University.

\section{Detection of Brucella antibodies}

Detection of Brucella antibodies in raw milk was done by using MRT. The test was carried out by adding one drop $(\sim 0.05 \mathrm{ml})$ of MRT antigen (JOVAC Jordan) to $1 \mathrm{ml}$ of whole milk in a narrow test tube $11 \times 100 \mathrm{~mm}$. The antigen milk mixtures were incubated at $37^{\circ} \mathrm{C}$ for $1-3$ hours. If the specific antibody is present in the milk it binds to the antigen and rise with the cream layer to form a blue ring above the white milk column. If antibodies are absent, the mixture remains homogeneously bluish-white throughout the tube (20).

\section{Isolation and Identification of Brucella}

Isolation of Brucella species from the raw milk samples was done under sterilized conditions, following standard procedures (21). Inoculated plates (Brucella broth and Brucella agar, HiMedia, India) were incubated aerobically and in the presence of $5 \%-10 \%$ carbon dioxide at $37^{\circ} \mathrm{C}$. The plates were observed for up to 7 days for the presence of suspected colonies of Brucella. Biochemical tests were employed for identification purposes of the suspected isolates (22).

\section{Sensitivity and Specificity of MRT}

The sensitivity and specificity of the MRT were calculated according to standard equations, using the bacterial isolation diagnostic method as a gold standard (23).

\section{Statistical analysis}

Data were analyzed using SPSS software version 15, confidence intervals were estimated using normal distribution approximation at an alpha level of 0.05 .

\section{Results}

\section{Occurrence of Brucella antibodies}

According to MRT, the overall rate of Brucella antibodies in raw milk samples was $8.6 \%$. The percentage of positive samples among cows group was $9.2 \%$ which is higher than the percent found in buffaloes group. Statistically, it is estimated that $5 \%$ - $12 \%$ (95\% confidence interval) of the cows and buffaloes would be seropositive for Brucella in Erbil governorate if screened by MRT assay (Table 1).

Table 1: Occurrence of Brucella antibodies among cow and buffaloes raw milk according to MRT

\begin{tabular}{lccc}
\hline Type of Milk & No & Positive (\%) & Negative (\%) \\
\hline Cow & 130 & $12(9.2)$ & $118(90.8)$ \\
Buffalo & 80 & $6(7.5)$ & $74(92.5)$ \\
\hline Total & 210 & $18(8.6)$ & $192(91.4)$ \\
\hline
\end{tabular}

\section{Occurrence of Brucella spp. in the milk samples}

The overall isolation proportion of Brucella species from raw milk samples was $7.1 \%(15 / 210)$. It is obviously clear that detection rate in both groups (cows and buffaloes)is more similar to each other (difference between groups is less than 1\%). Regarding the identified species of Brucella from raw milk samples, Br. abortus comprised two thirds $66.7 \%$ of total isolates (10/15 isolates), while the remaining isolates were of Br. melitensis (Table 2).

\section{Comparison of MRT to culture approach}

The MRT assay detected more cases of brucellosis $8.6 \%$ than traditional culture method $7.1 \%$ in both groups of cows and buffaloes. Sensitivity, specificity, positive predictive value (PPV) and negative predictive value (NPV) of MRT are given in Table 3. The efficiency (accuracy) of MRT in detecting bovine brucellosis is $97 \%$ in comparison to culture method, which candidates the MRT to be a good alternative screening/diagnostic method.

\section{Temporal Distribution of seropositive samples}

Variations of Brucella antibodies occurrence in raw milk samples during six months have been investigated (Table 4). The highest rate of incidence of Brucella antibodies detected by MRT was found in February $12.1 \%$, while the lowest rate was documented in June $5.7 \%$. Accordingly to the statistical calculations, there is a good correlation $\left(r^{2}=0.87\right)$ between the months and prevalence of brucellosis.

Table 2: Isolation of Brucella species from cow and buffaloes raw milk

\begin{tabular}{lccccc}
\hline Type of Milk & No & Positive (\%) & Negative (\%) & Br. abortus $\mathrm{n}(\%)$ & Br. melitensis $\mathrm{n}(\%)$ \\
\hline Cow & 130 & $10(7.7)$ & $120(92.3)$ & $7(70)$ & $3(30)$ \\
Buffalo & 80 & $5(6.3)$ & $75(93.7)$ & $3(60)$ & $2(40)$ \\
\hline Total & 210 & $15(7.1)$ & $195(92.9)$ & $10(66.7)$ & $5(33.3)$ \\
\hline
\end{tabular}


Table 3: The relationship between result of MRT and isolation of Brucella species from cow and buffalo's milk

\begin{tabular}{|c|c|c|c|c|c|c|c|c|}
\hline Type of Milk & No. & $\begin{array}{c}\text { MRT positive } \\
\text { n }(\%)\end{array}$ & $\begin{array}{c}\text { Culture positive } \\
\text { n }(\%)\end{array}$ & Sens. & Spe. & PVP & PVN & Effic. \\
\hline Cow & 130 & $12(9.2)$ & $10(7.7)$ & $83.3 \%$ & $98.3 \%$ & \multirow{3}{*}{$83 \%$} & \multirow{3}{*}{$98.5 \%$} & \multirow{3}{*}{$97 \%$} \\
\hline Buffalo & 80 & $6(7.5)$ & $5(6.3)$ & $83.3 \%$ & $98.7 \%$ & & & \\
\hline Total & 210 & $18(8.6)$ & $15(7.1)$ & $83.3 \%$ & $98.5 \%$ & & & \\
\hline
\end{tabular}

Sens; Sensitivity, Spe: Specificity, PVP; Predictive value positive, PVN; Predictive value negative, Effic.; Efficiency.

Table 4: Relation between months and prevalence of Brucella antibodies according to MRT during period of study

\begin{tabular}{lcccc}
\hline Month & $\begin{array}{c}\text { No. Examined Cow } \\
\text { positive }(\mathrm{n})\end{array}$ & $\begin{array}{c}\text { No. Examined Buffaloes } \\
\text { positive }(\mathrm{n})\end{array}$ & Total examined & $\begin{array}{c}\text { Total positive } \\
\mathrm{n}(\%)\end{array}$ \\
\hline January & $22(3)$ & $13(1)$ & 35 & $4(11.1)$ \\
February & $20(2)$ & $13(2)$ & 33 & $4(12.1)$ \\
March & $22(2)$ & $14(1)$ & 36 & $3(8.3)$ \\
April & $23(2)$ & $14(1)$ & 37 & $3(8.1)$ \\
May & $21(2)$ & $13(0)$ & 34 & $2(6.1)$ \\
June & $22(1)$ & $13(1)$ & 35 & $2(5.7)$ \\
\hline Total & $130(12)$ & $80(6)$ & 210 & $18(8.6)$ \\
\hline
\end{tabular}

\section{Discussion}

Brucellosis is a zoonotic disease affected domestic and wild animals. It is mainly a disease of food producing animals such as cattle, buffalo, camels, sheep, goats, and swine. Transmission to humans occurs in various ways, mostly via ingestion of contaminated food such as raw milk or meat or their products (9).

The difference in percentage of Brucella antibodies between cows $9.2 \%$ and buffaloes $7.5 \%$ groups is not significant and mostly owing to difference in sample size between cows and buffaloes groups. The result of overall occurrence is in agreement with previous studies from Yemen (20), Pakistan (24), and Kenya (25) where prevalence of Brucella antibodies ranged from 7\% to 9.7\% detected by MRT assay for raw milk samples from cattle and buffaloes. Indeed, lower rates of prevalence of Brucella antibodies were also reported from different countries. For instance, a Zimbabwean study (26) documented a $1.7 \%$ from a large sample size. While other reported rates ranged from $3 \%$ to $6 \%$ from Pakistan $(27,28)$ and India $(29,30)$. On the other hand, slightly higher incidences were reported in India $10.5 \%$ (31), Nigeria $15 \%$, Yemen $16 \%$, and India $18 \%$ (32-34). Moreover, higher prevalence rates were reported in India $27 \%$ (35), Uganda $33.5 \%$ (36), and in Egypt $51 \%$ and $49.8 \%$ for cows and buffaloes screened by MRT with an overall incidence of $47.8 \%$ (23). Such differences in prevalence may be attributed to many factors including husbandry and rearing practices, adherence for vaccination programs, herd size, cattle age and parity, among others $(37,38)$.
Isolation of Brucella is a difficult, tedious, timeconsuming, and potentially risky laboratory work. Therefore, most recent studies employ culture-independent diagnostic assays such as ELISA and PCR to detect the infection. The overall isolation rate of Brucella spp. in this study $7.1 \%$ is similar to a Nigerian study that detected brucellosis in livestock by the bacteriological approach (39).

It is well-known that $B r$. abortus has a preference for cattle over other ruminants, while $B r$. melitensis is the usual causative agent of brucellosis in goat and sheep animals (13). However, when cattle and buffalo are reared and cohoused with herds of goats and sheep, Br. melitensis infect and establish the disease in the cattle much similar to $B r$. abortus $(40,41)$. Currently, a growing literature reporting the isolation of $\mathrm{Br}$. melitensis from cattle is emerging worldwide but at low rates (42-46). Indeed, an Iraqi recent study isolated both of Br.abortus and Br. melitensis (overall rate is 3\%) from milk products (47). The isolation rate of Brucella in the present study is two-fold higher $7.1 \%$ than the previously mentioned Iraqi study. This difference may be attributed to the fact that Brucella cells may have been killed during industrial treatments for production of sampled milk products in the previous study. Additionally, sampling different area with different Brucella epidemiology or during the dry season may account for such variations in isolation rates. The isolation of Brucella from milk samples may be improved if more than one culture medium is used. On the other hand, higher isolation rates were also reported from different countries. In Syria, a recent study isolated $B r$. melitensis from bovine raw milk samples at a rate of $25 \%$ (48). Furthermore, in San Paulo, 
$30 \%$ of bovine screened milk samples yielded $B r$. abortus during a study of four years (49).

The sensitivity $83.3 \%$ and specificity $98.5 \%$ of MRT in comparison to culture approach clearly reveal its good value as a straightforward, inexpensive screening test to detect brucellosis in raw milk of cattle and buffaloes. However, a higher sensitivity $100 \%$ and lower specificity $75-73.5 \%$ has been reported for the MRT testing of cow and buffalo milk samples (23). It should be noted that both of culture method and MRT have low sensitivity in comparison to current molecular diagnostic techniques, but this drawback is compensated by the fact that the MRT is cheap and easy to perform. Meanwhile, ELISA and PCR approaches are expensive and unavailable in many developing countries. However, a recent Syrian study has found that PCR and culture approach yielded the same results while the MRT showed lower rates of positive results (48).

The temporal distribution of seropositive raw milk samples from cows and buffaloes shows good correlation $\left(\mathrm{r}^{2}=0.87\right)$ between the months and prevalence of brucellosis. The gradual decrease in the sero-positive rates of brucellosis in raw milk could be attributed to the gradual increase in temperature and/or gradual decrease in humidity and rain level in Kurdistan region during summer-autumn elapsing. For instance, wet season (odds ratio 3.7, 95\% CI 1.5-9.1) was found to be a risk factor for seropositive brucellosis in camel and goat populations (50). Larger sample size of milk samples for a complete year may reveal a clearer picture in term of Brucella prevalence rates and any association with certain months if any. To the best of author's knowledge, no study has monitored the bovine prevalence of brucellosis in a time span in Iraq or nearby countries. Moreover, There is scarcity of published data on the changing sero-prevalence of bovine brucellosis among seasons. Consequently, comparing and contrasting the finding of time-related seropositive rates is not possible currently.

In conclusion, the rate of brucellosis in cattle and buffalo population in Erbil Governorate is high and hazardous to humans. MRT can be used for rapid everyday monitoring of lactating cows and buffaloes due to its simple procedure for routine screening of Brucellosis in raw milk, and it its efficiency in comparison to laborious culturebased diagnosis especially in collection centers of milk and in dairy factories. Based on the presented findings, sufficient heating of raw milk is highly recommended to destroy this milk-borne bacterium. The epidemiology and seasonal variations in brucellosis rates in cattle and buffalo in Erbil is not fully clear. Further studies addressing this issue are highly recommended. Promotion of health awareness through the media (visual media, audio, and newspapers) is ad advised to highlight the method of transmission and prevention of animal and human brucellosis in order to control the disease in the food producing animals.

\section{References}

1. Geresu MA, Kassa, GM. A Review on Diagnostic Methods of Brucellosis. J Vet Sci Techno. 2016;7:3 . doi: 10.4172/21577579.1000323 .

2. Center for Food Security and Public Health. Brucellosis in Marine Mammals [Internet]. Institute for International Cooperation in Animal Biologics. Iowa State University, College of Veterinary Medicine. Technical Factsheets, 2018. Available from: http://www.cfsph.iastate.edu/DiseaseInfo/factsheets.htm.

3. Kardjadj M. The epidemiology of human and animal brucellosis in Algeria. J Bacteriol Mycol. 2016;3(2):1025.

4. Singh BB, Khatkar MS, Aulakh RS, Gill JP, Dhand NK. Estimation of the health and economic burden of human brucellosis in India. Prev Vet Med. 2018;154:148-55.

5. International Office of Epizootics. Biological Standards Commission, International Office of Epizootics. International Committee. Manual of diagnostic tests and vaccines for terrestrial animals: mammals, birds and bees. Office international des épizooties; 2018. Accessed on: 8 Nov. 2018. http://www.oie.int/standard-setting/terrestrialmanual/access-online/

6. Tuon FF, Gondolfo RB, Cerchiari N. Human- to- human transmission of Brucella-a systematic review. Trop Med Int Health. 2017;22(5):539-546.

7. Khan MY, Mah MW, Memish ZA. Brucellosis in pregnant women. Clin Infect Dis. 2001;32(8):1172-1177.

8. Mor SM, Wiethoelter AK, Massey PD, Robson J, Wilks K, Hutchinson P. Pigs, pooches and pasteurisation: The changing face of brucellosis in Australia. Aust J Gen Pract. 2018;47(3):99-103.

9. Centers for Disease Control and prevention (CDC). Brucellosis reference guide: Exposures, testing, and prevention [Internet]. 2017. Available from: https://www.cdc.gov/brucellosis/pdf/brucellosireference-guide.pdf

10. Babaoglu UT, Ogutucu H, Demir G, Sanli D, Babaoglu AB, Oymak S. Prevalence of Brucella in raw milk: An example from Turkey. Niger J ClinPract. 2018;21(7):907-911.

11. Franc KA, Krecek RC, Häsler BN, Arenas-Gamboa AM. Brucellosis remains a neglected disease in the developing world: a call for interdisciplinary action. BMC Public health. 2018;18(1):125. DOI 10.1186/s12889-017-5016-y.

12. Muyumba NA, RamazaniM NK, KhangImvar Esther L, Roger KM. Prevalence of Caprine and Human Brucellosis Estimated at Slaughterhouses Processing Grilled Meat and Female Goat Meat Traders Consumed in Lubumbashi Neighborhoods, Democratic Republic of Congo. Int J Pure App Biosci. 2017;5(1):18-23.

13. Carroll KC, Hobden JA, Miller S, Mitchell TG, Morse SA, Mietzner TA, Detrick B, McKerrow JH, Sakanari A. Jawetz, Melnick\&Adelberg's Medical Microbiology $27^{\text {th }}$ ed. New York: McGraw-Hill Co.; 2016. 269-271 p.

14. Tille PM. Bailey and Scott's Diagnostic Microbiology $14^{\text {th }}$ ed. Philadelphia: Mosby Elsevier; 2017. 470-474 p.

15. Scholz HC, Revilla-Fernández S, Al Dahouk S, Hammerl JA, Zygmunt MS, Cloeckaert A, Koylass M, Whatmore AM, Blom J, Vergnaud G, Witte A. Brucellavulpis sp. Nov., isolated from mandibular lymph nodes of red foxes (Vulpesvulpes). Int $\mathbf{J}$ SystEvolMicrobiol. 2016;66(5):2090-2098.

16. Sabrina R, Mossadak HT, Bakir M, Asma M, Khaoula B. Detection of Brucella spp. In milk from seronegative cows by real-time polymerase chain reaction in the region of Batna, Algeria. Vet world. 2018;11(3):363-367

17. Jaff D. Brucellosis in Iraqi Kurdistan: an overview. J EntomolZool Stud. 2016;4(4):1113-1115. 
18. Pal M, Gizaw F, Fekadu G, Alemayehu G, Kandi V. Public Health and Economic Importance of Bovine Brucellosis: An Overview. Am J Epidemiol Infect Dis. 2017;5(2):27-34.

19. AL-Shemmari IG. Comparative study between conventional and molecular tests to detect the incidence of brucellosis in cattle and buffaloes in Babylon and Karbala provinces. Sci J Med Res. 2018;2(5):7-13.

20. AL-mashhadany DA. Prevalence of bovine brucellosis in Thamar province/Yemen. Yem J Agr Res Stud. 2009;20:17-26.

21. Corbel MJ, Alton GG, Banai M. Brucellosis in humans and animals: Produced by the World Health Organization in collaboration with the Food and Agriculture Organization of the United Nations and World Organisation for Animal Health. Health WHO/CDS/EPR. 2006. Available from: http://www.who.int/csr/resources/publications/ Brucellosis.pdf

22. AL-Mashhadany DA. Prevalence of Brucellosis in Human and Camels in Thamar Province/Yemen. J Saudi SocAgric Sci. 2014;13:132-137.

23. Ibrahim AK, AbdelAll AA, Amin AS. Long-term diagnostic studies for detection of Brucella spp. In milk samples. Glob Vet. 2012;8:5461.

24. Saleha S, Basit A, Rahim K, Shahid M, Khan MA. Comparison of milk ring test; serum plate agglutination test and polymerase chain reaction for the detection of bovine brucellosis. Res J Vet Pract. 2014;2:5-8

25. Mbaire MR. Prevalence and Knowledge of Brucellosis in dairy cattle in Makuyu Division, MurangaCounty, Kenya [master's thesis]. The School of Pure and Applied Sciences of Kenyatta University; 2014.

26. Vhoko K, Iannetti S, Burumu J, Ippoliti C, Bhebhe B, DeMassis F. Estimating the prevalence of Brucellosis in cattle in Zimbabwe from samples submitted to the Central Veterinary Laboratory between 2010 and 2014. Vet Ital. 2018;54(1):21-27.

27. Khan TI, Ehtisham-ul-Haque S, Waheed U, Khan I, Younus M, Ali S. Milk Indirect-ELISA and Milk Ring Test for Screening of Brucellosis in Buffaloes, Goats and Bulk Tank Milk Samples Collected from Two Districts of Punjab, Pakistan. Pak Vet J. 2018;38(1):105-108.

28. Bakhtullah FP, Shahid M, Basit A, Khan MA, Gul S, Wazir I, Raqeebullah KR. Sero-prevalence of brucellosis in cattle in southern area of Khyber Pakhtunkhwa, Pakistan. Res J Vet Pract. 2014;2:6366.

29. Raghava S, Gowda MH, Shome R, Kulkarni M, Umesha S. Epidemiological and Molecular Characterization of Brucella Species in Cattle. Asian J Anim Sci. 2017;11(3):123-131.

30. Kumar VN, Bharathi MV, Porteen K, Sekar M. Milk ring test as ready aid to diagnose bovine brucellosis in lactating cows of Tamil Nadu, India. Adv Dairy Res. 2016;10:1-4.

31. Gogoi SB, Hussain P, Sarma PC, Barua AG, Mahato G, Bora DP, Konch P, Gogoi P. Prevalence of bovine brucellosis in Assam, India. J Entomol Zool Stud. 2017;5(4):179-185.

32. Mohamand N, Gunaseelan L, Sukumar B, Porteen K. Milk Ring Test for spot identification of Brucella abortus infection in single cow herds. J Adv Vet Anim Res. 2014;1(2):70-72.

33. Abdul-Razag WMAA. Serological and Bacteriological Study on Brucellosis in Human and Food Producing Animals in Thamar Province [master's thesis]. Dhamar: Thamar University, Yemen; 2015.
34. Ior DD, Chukwu CC. Prevalence of Brucella antibodies in marketed cow milk in Benue State, Nigeria. Afr $\mathbf{J}$ Microbiol Res. 2015;9(28):1752-1757.

35. Dubey P, Patel KB, Patel BK, Chauhan HC, Chandel BS, Patel SS, Shrimali MD, Kala JK, Patel MG, Patel AC, Rajgor M. Molecular Detection of Brucella Organism from Milk and Milk Products. Int J CurrMicrobiol App Sci 2017;6(4):1087-1091.

36. Kamwine M, Orikiriza P, Taseera K, Iramiot JS, Ojuka P, Ikiriza S, Atwebembeire J, Otieno D, Tweshengyereze S, Mwanga-Amumpaire J, Bazira J. Prevalence of antibodies to Brucella species in commercial raw bovine milk in Southwestern Uganda. BMC Res notes. 2017;10(1):215. doi: 10.1186/s13104-017-2537-5.

37. Makita K, Fèvre EM, Waiswa C, Eisler MC, Thrusfield M, Welburn SC. Herd prevalence of bovine brucellosis and analysis of risk factors in cattle in urban and peri-urban areas of the Kampala economic zone, Uganda. BMC Vet Res. 2011;7(1):60.

38. Yilma M, Mamo G, Mammo B. Review on brucellosis seroprevalence and ecology in livestock and human population of Ethiopia. Ach Life Sci. 2016;10(1):80-86.

39. Ocholi RA, Kwaga JK, Ajogi I, Bale JO. Phenotypic characterization of Brucella strains isolated from livestock in Nigeria. Vet Microbiol. 2004;103(1-2):47-53.

40. López-Merino A. Brucellosis in Latin America. In: Young EJ, Corbel MJ, Eds. Brucellosis clinical and laboratory aspects. Boca Raton: CRC Press; 1989. 151-161 p.

41. Godfroid J, Käsbohrer A. Brucellosis in the European Union and Norway at the turn of the twenty-first century. Vet Microbiol. 2002;90:135-145.

42. Adesiyun AA, Baird K, Stewart-Johnson A. Antimicrobial resistance, phenotypic characteristics and phage types of $B$. abortus strains isolated from cattle and water buffalo (Bubalusbubalis) in Trinidad. Vet Arch. 2011;81:391-404.

43. Priyantha MA. Identification of biovars of Brucella abortus in aborted cattle and buffaloes herd in Sri Lanka. Vet World. 2011;4(12):542.

44. Martinez-Herrera DI, Pulido-Camarillo E, Pardio-Sedas VT, LopezMerino A, del Carmen Sarabia-Bueno C, Loeza-Limon R, MoralesAlvarez JF, Flores-Castro R. Isolation of Brucella abortus from the milk of serum positive cows using chiken embryos as amplifier. Afr J Microbiol Res. 2012;6(18):4036-4040.

45. Tae H, Shallom S, Settlage R, Hawkins GN, Adams LG, Garner HR. Complete genome sequence of Brucella suis VBI22, isolated from bovine milk. J bacteriol. 2012;194(4):910.

46. World Health Organization (WHO), 2012. Neglected zoonotic diseases (NZD) [Internet]. In: http://www.who.int/ neglected_diseases/zoonoses/en/, Accessed 07 November, 2018.

47. Abbas BA, Talei BA. Isolation, identification and biotyping of Brucella spp. From milk product at Basrah Province. Basrah J Vet Res. 2010;9(1):152-162.

48. Al-Mariri A. Isolation of Brucella melitensis strains from Syrian bovine milk samples. Bulg J Vet Med. 2015;18(1):40-48.

49. Langoni H, Ichihara SM, da Silva AV, Pardo RB, Tonin FB, Mendonça LJ, Machado JA. Isolation of Brucella spp. from milk of brucellosis positive cows in São Paulo and Minas Gerais states. Braz J Vet Res Anim Sci. 2000;37(1/6):444-448.

50. Megersa B, Biffa D, Abunna F, Regassa A, Godfroid J, Skjerve E. Seroepidemiological study of livestock brucellosis in a pastoral region. Epidemiol Infect. 2012;140(5):887-896. 